\title{
Expanding the Reach of Biosemiotics
}

\author{
Yogi Hale Hendlin ${ }^{1,2,3}$
}

Received: 14 April 2021 / Accepted: 14 April 2021 / Published online: 29 April 2021

(C) The Author(s), under exclusive licence to Springer Nature B.V. 2021

\section{Adaptation and Enlivenment}

My first initiation into biosemiotics was while I was writing my dissertation on interspecies communication around 2010. I was interested in exploring how Jürgen Habermas' theory of communicative action could work across species boundaries, through the help of feminist and postcolonial friendly critics of discourse ethics such as Nancy Fraser, Iris Marion Young, and Charles W. Mills. However, this was only half of the story of how humans could widen our circle of concern to include the whole 'polity,' so to speak. The other half, the biological half of how we actually pick up on and understand signals very different from our own communicative habits dominated by symbolic language, required reaching into the recesses of zoosemiotics and phytosemiotics, eventually landing me by fortune to discover the thriving field of biosemiotics. I remember attending my first biosemiotics event, the Framing Nature conference at the University of Tartu in 2014, and getting to meet so many of those whose texts had inspired me (among many others, Kalevi Kull, one of the organizers, and Wendy Wheeler, who gave the Jakob von Uexküll plenary lecture). The feeling at the conference was electric, and the opportunity to publish my presentation "Multiplicity and Welt" in Sign System Studies, my first conscious contribution to the interdiscipline, ushered me into the academically rigorous yet encouraging gathering of biosemioticians. I came for the scholarly insights - after all, biosemiotics works at the interstices of philosophy, biology, systems sciences, and semiotics. But I stayed for the camaraderie; the warm welcome I and many have felt in this community, which inspires us to find our unique contribution to the interdiscipline, and to learn about the various facets of biosemiotics' history and journey.

In accepting the invitation to become lead Editor-in-Chief of the journal starting 2021, I surveyed the changing ecology in which biosemiotics steers, and how the fielditself is at a

Yogi Hale Hendlin

Hendlin@esphil.eur.nl

1 Erasmus School of Philosophy, Erasmus University Rotterdam, Postbus 1738, 3000

DR Rotterdam, The Netherlands

2 Dynamics of Inclusive Prosperity Initiative, Erasmus University Rotterdam, Rotterdam, Netherlands

3 Environmental Health Initiative, University of California, San Francisco, San Francisco, CA, USA 
crossroads. With biology's most fascinating insights coming from the trajectory loosely assembled as the Extended Evolutionary Synthesis, the importance of the Umwelt and interorganism meaning-making has never been more present in the biological sciences since their origins. While slightly different language is used by different biologists and biosemioticians, the phenomena we are getting at is the same. Likewise in cognitive science and the philosophical school of phenomenology, where enactivists and other emergentist, ecological, embedded, extended, and affective modes of mind are seen as connected to the organism's Umwelt (social and ecological milieu). In Peirce studies too, biosemiotics is also one of the most vibrant areas utilizing Peirce's semiotics in novel applications. In ethology and participatory action research, the insights from biosemiotics help dissolve the anthropocentric and anthropomorphic blocks to scientific understandings of radically different organisms. One could go on, including general systems theory and the many allied fields supportive of and inspired by biosemiotic inquiry. Thus, biosemiotics, in its commitment to attend to the ways in which (other) organisms make meaning of the world, the specific subsection of reality they (we) perceive as their species-specific Umwelt, not only faithfully returns with less muddied epistemological knowledge, but in doing so, also promises to herald a more ethical relationship between human action and other organisms as well. Attending is caring, and caring requires attending beyond our species-specific assimilations of how meaning is made.

This journal serves as a place for publishing findings of the international Umwelt research laboratory made up of the community of biosemioticians and our colleagues in adjacent disciplines. In the coming years, we look forward to including more material from biologists working on meaning-making, ethologists sharing their methodologies and research achieving interspecies biosemiosis, scholars able to quantify biosemiosis without reducing it to current measurement tools, ecologists and systems thinkers sensitive to the co-construction of environments by organisms, and semioticians, anthropologists, philosophers, and others forwarding the meta-conversation in both the 'hard' and 'soft' life sciences. Of course, research on informatics, cybernetics, and the many other topics and fields our journal has published continue to be welcome. Our mission is to forward biosemiotic understandings of science and society to enable more accurate and informed ontological, ethical, and epistemological viewpoints and relations in our biosphere.

Taking up this role of Editor-in-Chief also prompted reflection on all those whose leadership at this journal has developed the discipline into an oasis for robust transdisciplinary dialog. Most immediately prior, I'd like to thank previous Editor-in-Chief Morten Tønnessen for his many years of leadership at the journal, as well as Filip Jaroš, and Timo Maran. Marcello Barbieri, the journal's first Editor-in-Chief, helped launch Biosemiotics in 2008. And finally, Alexei Sharov, my fellow current Editor-in-Chief, deserves thanks for his steady and indispensable guidance of the journal.

In the current iteration of Biosemiotics, we have shifted from three Editors-in-Chief to two; but have expanded the journal leadership to include five Associate Editors plus an Intern. We are grateful for all of their contributions towards making this journal run smoothly and to expanding Biosemiotics' reach and capacity. One reason for the need for this greater capacity is to accommodate the new article type of Target Articles and Commentaries pioneered by Morten Tønnessen. It is my pleasure to work with the Editorial Board of Biosemiotics, the Associate Editors and Intern, and the Members and Executive Board of the International Society for Biosemiotic Studies in continuing their devoted work in this tradition. 
Starting with this issue, in addition to previous formats (e.g., Reviews, Original Research, Book Reviews, Short Communications, Glossary Entries), we introduce the Target Article and accompanying invited Commentaries. This format allows for deep real-time debates on relevant issues and thorny topics, showcasing a provocative paper by a leading biosemiotician or luminary in an intersecting field, combined with intense commentaries from diverse positions in response.

\section{Introducing Biosemiotics' First Target Article}

This issue's Target Article is on "The Illusions of the Modern Synthesis," written by the renowned systems biologist Noble (2021). Noble's article reviews the history of evolutionary theory from Darwin to Dawkins beyond to the Extended Evolutionary Synthesis, considering how these developments interact with biosemiotics. Noble was first recognized for his pioneering work achieving a mathematical model for the living heart's emergent oscillations, and has become a chief proponent of the Extended Evolutionary Synthesis (EES), authoring the accessible and acclaimed systems biology books The Music of Life: Biology beyond the Genome and Dance to the Tune of Life: Biological Relativity. Professor Noble was Burdon Sanderson Chair of Cardiovascular Physiology at the University of Oxford from 1984 to 2004, and is currently Professor Emeritus and co-Director of Computational Physiology with the Department of Physiology, Anatomy \& Genetics, University of Oxford. An elected fellow of the Royal Society since 1979, and Honorary Member of the Royal College of Physicians since 1989, he has published hundreds of papers and many books, making Noble one of the most prolific biologists of the past 50 years.

In a 2007 paper in Experimental Physiology based on his Paton Lecture delivered the same year to the Life Sciences annual meeting, Noble expands the history of Claude Bernard, who he knights as the first systems biologist. In that paper, Noble proposed the now familiar ten 'principles of systems biology':

1. Biological functionality is multi-level.

2. Transmission of information is not one way.

3. DNA is not the sole transmitter of inheritance.

4. The theory of biological relativity: there is no privileged level of causality.

5. Gene ontology will fail without higher-level insight.

6. There is no genetic program.

7. There are no programs at any other level.

8. There are no programs in the brain.

9. The self is not an object.

10. There are many more to be discovered; a genuine 'theory of biology' does not yet exist (Noble, 2007, p. 17-25).

These principles helped crystalize the already productive EES research paradigm, which has brought us the science of epigenetics, holobionts, genomic evolution, and the theoretical scaffolding of ecological evolutionary developmental biology.

To reiterate Noble's quote of Claude Bernand, "The living organism does not really exist in the milieu exterieur but in the liquid milieu interieur"(2007, p. 17). In Uexküllian parlance, it is the Innenwelt of the organism which makes it an organism, rather than a mere surface or material, like volcanic rock or a grain of sand. The 
importance that this milieu interieur be "liquid" also suggests its semiotic nature: inner worlds adjust in interaction with outward phenomena. The interactions an organism experiences, on a physiological level prompted by both membrane "in" and membrane "out" interactions, make up its behavioral patterns which then (continue to) supervene on its physiology. Or to repurpose a hackneyed question, which came first? The organism? Or the niche? These looping effects between genetics and environment, including but not only epigenetics, create a dynamic esse in futuro - where the ontology of the organism is historically determined but flexible and amendable as future interactions become part of it.

Noble's contribution to biosemiotics is immense. His notion of biological relativity, that the laws of biology themselves fluctuate according to the perspective taken and local circumstances reinjects into the deterministic "clockwork" version of evolution the spark of meaning in organisms actively (if unconsciously) playing decisive roles in their own evolution (and mostly unwittingly, the evolution of other organisms which intersect with their Umwelt). This interactive version of evolution acknowledges the adjacent next of current states, replacing the spooky invisible hand of natural selection with the agency of organisms (and semiosis at all levels) choosing and deciding - and thus selecting - for given desires and advantages. By retracing Darwin's steps, Noble's lifework, displayed in nuce here, imparts a profound wonder for the array of agents contributing to selection, pointing out in detail that organisms meaningfully engaging with their circumstances brings about novel events which supervene on both their environment and in turn their own synergies and constraints.

With twenty Commentaries from biologists, chemists, evolutionary theorists, philosophers of biology, historians, and other scholars, Noble's Target Article has hit on themes central to biosemiotics and beyond. His critics and colleagues often note the ecological factors which have created the scientific understandings and debates presented; science does not occur in a vacuum, but akin to the subtitle of philosopher of science Steven Shapin's book Never Pure, it behooves us to recognize Historical Studies of Science as if It Was Produced by People with Bodies, Situated in Time, Space, Culture, and Society, and Struggling for Credibility and Authority.

Next issue's Target Article is titled "How Molecules became Signs," authored by neuroanthropologist and biosemiotician Terrence Deacon, who has brought into the public sphere C.S. Peirce's modeling of different sign types (icon, index, symbol) in The Symbolic Species, and whose work on autogens (the most basic model of purpose or agency creating order from entropy, such as a virus) in Incomplete Nature: How Mind Emerged from Matter has investigated the origins of biosemiosis.

\section{References}

Noble, D. (2007). Claude Bernard, the first systems biologist, and the future of physiology. Experimental Physiology, 93(1), 16-26. https://doi.org/10.1113/expphysiol.2007.038695.

Noble, D. (2021). The Illusions of the modern synthesis. Biosemiotics, 14(1). https://doi.org/10.1007/s12304021-09405-3.

Publisher's Note Springer Nature remains neutral with regard to jurisdictional claims in published maps and institutional affiliations. 